\title{
Distribution, Characterization and Health Risk Assessment of Manganese in Vegetables and Root Tubers from Gokana, Rivers State, Nigeria
}

\author{
Kpobari W Nkpaa*, Benjamin A Amadi and Matthew 0 Wegwu \\ Department of Biochemistry, University of Port Harcourt, Nigeria
}

Submission: October 27, 2017; Published: December 15, 2017

*Corresponding author: Kpobari W Nkpaa, Department of Biochemistry, (Environmental Toxicology Unit), Faculty of Science, University of Port Harcourt, PMB 5323, Choba, Rivers State, Nigeria, Email: nkwilly@gmail.com; kpobari_nkpaa@uniport.edu.ng

\begin{abstract}
Food safety and toxic metals accumulation in agricultural soil and food crops grown on such soils are major concern globally as a result of their significant health risks. Soil is considered as the major sources of toxic metals. This study was designed to evaluate the Manganese (Mn) level in vegetables, root tubers and agricultural soils in six communities in Gokana, Rivers State, Nigeria using spectrophotometric method. Mn transfer from soil-to-plant, average daily intake, and human health risk were also calculated. The level of Mn in vegetables and root tubers ranged between $2.19 \pm 0.23-28.4 \pm 1.27 \mathrm{mg} / \mathrm{kg}$ and $8.11 \pm 0.99-56.4 \pm 2.12 \mathrm{mg} / \mathrm{kg}$, respectively. While $\mathrm{Mn}$ in vegetables and root tubers associated soils ranged between $27.1 \pm 1.18-88.4 \pm 1.77 \mathrm{mg} / \mathrm{kg}$ and $33.4 \pm 1.84-92.3 \pm 1.39 \mathrm{mg} / \mathrm{kg}$, respectively across the various study sites. The higher bioconcentration factor (BCF) was obtained for cassava from B-Dere, Gbe and Bodo City. About $55.2 \%$ of THQ calculated were $>1$. In this study, the daily intake of $\mathrm{Mn}$ via the consumption of vegetables and root tubers are more likely to pose severe health risks to exposed population in Gokana and children are more susceptible to Mn toxicity than adults.
\end{abstract}

Keywords: Food safety; Manganese; Vegetables; Root tubers; Health risk; Gokana

\section{Introduction}

Food safety and toxic metals accumulation in agricultural crops are major concern globally as a result of their significant health risks [1-4]. Toxic metals are usually non-biodegradable and are characterized by long biological half-lives. Majority of them have the potential to bio-accumulate in different organs in the body and cause health effects [5-8]. The water solubility of toxic metals contributes to their contamination potentials $[9,10]$. Excessive of Manganese ( $\mathrm{Mn}$ ) levels in the environment is of great concern to environmental scientist because of its neurotoxicity potentials. Despite its relevance to normal physiological and biochemical functions to the body, it is extremely toxic in when in excess in the body. Bio-accumulation of $\mathrm{Mn}$ in the basal ganglia structure may lead to a neurodegenerative disease called manganism, its motor symptoms include bradykinesia, dystonia and rigidity [11-13]. The symptoms of this parkinsonian-like syndrome include an early stage of neuropsychiatric disorder (locura manganica), with behavioral symptoms such as memory loss, hallucinations, nervousness, cognitive deficits, bizarre behaviors and flight of ideas, in addition to the Parkinson's-like effects related to motor dysfunction [14- 17].
The bio-concentration factor also called transfer factor of toxic metals from agricultural soil to vegetables and root tubers is one of the most important pathway in which humans are exposed via consuming such food crops. Bioaccumulation of toxic metals in the vegetables and root tubers is affected by different factors such as atmospheric dry depositions, local climate, atmospheric dry depositions, soil electrolytes, electrochemical properties and the degree of maturity of plants during harvesting time $[18,19]$. Industrial activities, crude oil spill, additions of manures, agrochemicals sludge are major human activities that contributes to toxic metals contamination in agricultural farmlands and soil uptake of toxic metals via amending the physiochemical properties of the soil [20].

In the environment like Gokana where there is strong evidence of toxic metals contamination [21,22], vegetable and root tubers contamination by toxic metals cannot be undervalued because vegetables and root tubers are very important to human diet as they comprise important constituents desired by the human body, like carbohydrates, proteins, vitamins, minerals, and trace elements [23]. It has been reported that heavy metals 
enter into the food chain via consumption of food crops [24] such as vegetables and root tubers. This may lead to bioaccumulation of toxic metals in the organs in the body and lead to disease conditions [9]. Because of these possibilities there is need to analyzed food crops and estimate the health risk associated with contaminated food crops regularly to ensure that human is safe from toxic metals and also to ensure that food crops from this region meets the required international standard for agricultural food products, especially where toxic metals in food items are limited $[10,25]$.

The people of Gokana are majorly involved in farming for food and business. The vegetables and root tubers are grown in crude oil spill contaminated environment resulting from artisanal bunkery and pipe line failure. These vegetables (pumpkin, waterleaf, bitter leaf and scent leaf) and root tubers (yam, water yam, cocoyam and cassava) are supplied to Kibangha market in Gokana local government area; a major market serving the population in Rivers State. No previous research work investigating the human health risk assessment via dietary intake of vegetables and root tubers in Gokana existed. Therefore, this research was designed to investigate the levels of Mn in edible parts of vegetables and root tubers and to evaluate the pollution index and human health risks associated with them.

\section{Materials and Methods}

Gokana Local Government Area is located in Ogoniland, Rivers State, Nigeria and has both upland and riverine (coastal) communities. Its comprises of 17 autonomous communities, $50 \%$ of these communities are heavily polluted by crude oil spill. The Gokana people are mostly farmers and fishermen who depend mostly on farm produce and fish for food and was one of the major oil-producing areas in Rivers State. It a region in Niger Delta covering some $1000 \mathrm{~km}^{2}$ in the southeast of the Niger Delta basin. Gokana shares boundaries with Khana in the east, Tai in the north, Bonny in the South and Ogu/Bolo in the west. The LGA is situated about $30 \mathrm{~km}$ from Onne Industrial area and $50 \mathrm{~km}$ south of Port Harcourt. It is located at the following geographical coordinate: latitude $4^{\circ} 40^{\prime} 5^{\prime \prime} \mathrm{N}$ and $4^{\circ} 43^{\prime} 19.5^{\prime \prime} \mathrm{N}$ and longitude $7^{\circ} 22^{\prime} 53.7^{\prime \prime} \mathrm{E}$ and $7^{\circ} 27^{\prime} 9.8^{\prime \prime} \mathrm{E}$ [21,22].

\section{Sample Collection}

Vegetables and root tubers were harvested during harvest period from six (6) coastal and densely populated communities heavily contaminated with crude oil spill in Gokana Local Government Area. In each of the six community, vegetables (pumpkins, bitter leaves, water leaves, and scent leaves), root tubers (yam, coco yam, water yam and cassava) along with the soils samples were collected from six (6) farmlands. The soil samples were taken $10-15 \mathrm{~cm}$ below the surface using a stainless trowel and gently shaken off from the root tubers and vegetables roots. All these samples were carefully sealed in polyethylene bags and immediately transported to the laboratory $[23,24]$.

\section{Sample preparation and digestion}

Edible parts of the vegetables and root tubers were washed with deionized water to remove dirt and other airborne pollutants. Thereafter, they were weighed and air dry for 24 hours to a constant weight or to reduce the water content. The vegetables and root tubers were then oven-dried at $70-80{ }^{\circ} \mathrm{C}$ for 24 and 72 hours, respectively. The dried samples were pulverized with a pestle and motor before being sieved via 80 Muslin sieve $(0.2 \mathrm{~mm})[23,25]$.

\section{Analysis of manganese in plant and soil}

Two (2) grams of the vegetables and root tubers were weighed accurately and place in crucible to ash. The ash content was then digested in a mixture of $\mathrm{HNO}_{3}-\mathrm{HClO}_{4}-\mathrm{H}_{2} \mathrm{O}_{2}$ (87:13:10, $\mathrm{v} / \mathrm{v} / \mathrm{v}$ ). While $0.5 \mathrm{~g}$ of the air-dried soil samples were thoroughly mixed with $6 \mathrm{~mL}$ of concentrated $\mathrm{HNO}_{3}-\mathrm{HCIO}_{4}(87: 13, \mathrm{v} / \mathrm{v})$ and $6 \mathrm{~mL}$ of concentrated $\mathrm{HCl}$. The mixture was thereafter digested and dissolved in $2 \% \mathrm{HCl}$ solution. The levels of $\mathrm{Mn}$ in the vegetables, root tubers and soil samples were analyzed with atomic absorption spectrophotometer (AAS) equipped with graphite furnace(AAnalyst 700 Perkin-Elmer) at a wavelength of $279.50 \mathrm{~nm}$ [24].

\section{Bio-concentration factor (BCF)}

The bio-concentration factor (BCF), which measured the transfer capability of a metal uptake from the soil to the plant was evaluated using the formula below:

$$
B C F=\frac{\text { Cplant }}{\text { Csoil }}
$$

Where Cplants the level of manganese in the vegetable and root tubers $(\mathrm{mg} / \mathrm{kg})$, while and Csoil is the corresponding manganese level in the soil habitat of the vegetable and root tubers (mg/kg).

The bio-concentration factor of Mn from soil to the food crops parts was calculated to evaluate the relative uptake of $\mathrm{Mn}$ by the vegetables and root tubers with respect to soil [24]. Over the years, environmental scientists have used the ratio of metals between soil and plant parts as an important parameter for the assessment of soil contaminated with high level of heavy metals. When the ratio is $>1$, it indicates higher bio-accumulation of metals in plant parts than soil. BCF value of a metals is influenced by many factors such as was influenced by different factors such as soil electrolyte, metal chemistry, electrochemical properties (such as temperature, $\mathrm{pH}$ ) and the type of plant. One of the important pathways for human exposure to metals is via the translocation of metals from soil to food crops.

\section{Concentration factor}

Contamination factor (CF) was evaluated by using the model defined by Lacatusu [26] and Ihedioha et al. [27]. CF is used to evaluate the degree of contamination of soil by metals. It's directly reveals the pollution of environmental indicator 
because it's used the single pollution index. The formula used is shown below:

$$
C F=\frac{\text { Csoil }}{T \text { arg et(Background }) \text { Values }}
$$

Where CF is the concentration factor, Csoil is the concentration of manganese in the soil. Target (background) value is a reference value of metals $(\mathrm{mg} / \mathrm{kg})$, the reference adopted in this present for Mn was 476. This was obtained from the Department of Petroleum Resources (DPR) of Nigeria standard formulated table [28] for maximum allowable Mn concentration in Nigerian soil. Pollution range is defined by $\mathrm{CF}$ values greater than one while contamination range is defined by $\mathrm{CF}$ values lower than one. The standard employed by Lacatusu [26] was used to interpret soil Mn contamination/pollution index, although this varies from country to country. The Significance intervals of contamination/ pollution factor (CF) used in this present was previously adopted by Lacatusu [26], where observed CF values indicates different contamination and pollution level as shown in Table 1.

Table 1: The Significance intervals of contamination/ pollution factor (CF) values and its implications.

\begin{tabular}{|c|c|}
\hline CF Values & Descriptions \\
\hline$<0.1$ & Very slight contamination \\
\hline $0.10-0.25$ & Slight contamination \\
\hline $0.26-0.50$ & Moderate contamination \\
\hline $0.51-0.75$ & Severe contamination \\
\hline $0.76-1.00$ & Very severe contamination \\
\hline $1.10-2.00$ & Slight pollution \\
\hline $2.10-4.00$ & Moderate pollution \\
\hline $4.10-8.00$ & Severe pollution \\
\hline $8.10-16.0$ & Very severe pollution \\
\hline$>16.0$ & Excessive pollution \\
\hline
\end{tabular}

\section{Estimated Daily Intake (EDI)}

The Estimated Daily Intake (EDI) rate of metals was calculated using the equation below:

$$
E D I=\frac{C v \times I R \times E F \times E D}{B w \times A T}
$$

\section{Results and Discussion}

\section{Manganese levels in vegetables and root tubers}

Table 2: Manganese level (mg/kg) in vegetables and root tubers from Gbe, Mogho, B-Dere, K-Dere, Kpor and Bodo City, Gokana Local Government Area, Ogoniland, Rivers State, Nigeria.

\begin{tabular}{|c|c|c|c|c|c|c|}
\hline & \multicolumn{7}{|c|}{ Mn } & \multicolumn{2}{c|}{ K-Dere } & Kpor & Bodo City & 0.14 & 0.14 \\
\hline WHO/USEPA & 0.14 & Mogho & 0.14 & 0.14 & $7.89 \pm 1.99$ & $4.13 \pm 0.11$ \\
\hline Pumpkin & $28.4 \pm 1.27$ & $16.4 \pm 1.23$ & $13.4 \pm 1.27$ & $11.4 \pm 1.82$ & $4.71 \pm 0.84$ & $22.9 \pm 2.09$ \\
\hline Bitter leaf & $10.4 \pm 1.43$ & $9.13 \pm 1.41$ & $6.72 \pm 1.61$ & $6.49 \pm 1.41$ & $2.19 \pm 0.23$ & $27.8 \pm 2.16$ \\
\hline Water leaf & $14.9 \pm 2.43$ & $14.1 \pm 1.12$ & $8.43 \pm 1.13$ & $6.48 \pm 1.22$ & $4.11 \pm 0.18$ & $16.4 \pm 1.77$ \\
\hline Scent leaf & $8.43 \pm 1.83$ & $8.34 \pm 0.19$ & $19.7 \pm 1.36$ & $37.1 \pm 2.11$ & $31.7 \pm 2.34$ & $10.8 \pm 1.71$ \\
\hline Yam & $41.8 \pm 2.83$ & $53.1 \pm 2.45$ \\
\hline
\end{tabular}




\begin{tabular}{|c|l|l|l|l|l|l|}
\hline Cocoyam & $27.4 \pm 2.34$ & $9.10 \pm 1.41$ & $28.4 \pm 2.33$ & $24.1 \pm 1.36$ & $8.11 \pm 0.99$ & $38.4 \pm 1.42$ \\
\hline Wateryam & $18.7 \pm 1.75$ & $13.9 \pm 0.12$ & $17.3 \pm 2.18$ & $19.8 \pm 1.48$ & $13.1 \pm 0.71$ & $22.8 \pm 1.39$ \\
\hline Cassava & $56.4 \pm 2.12$ & $21.5 \pm 1.91$ & $41.4 \pm 1.43$ & $35.6 \pm 2.61$ & $19.3 \pm 1.44$ & $61.3 \pm 2.75$ \\
\hline
\end{tabular}

The levels of Mn in the leafy vegetables and root tubers are presented in Table 2 . The Mn contents of most vegetables were found to be significantly different $(p>0.05)$ when compared with recommended permissible level recommended by US EPA guidelines. The level of $\mathrm{Mn}$ in vegetables and root tubers ranged between $2.19 \pm 0.23-28.4 \pm 1.27 \mathrm{mg} / \mathrm{kg}$ and $8.11 \pm 0.99$ $56.4 \pm 2.12 \mathrm{mg} / \mathrm{kg}$ respectively across the various study sites. Mn level in vegetables and a root tuber indicates that Bodo City is heavily contaminated when compared with the other study sites. Metals, especially $\mathrm{Mn}$ enter into the food chain via bioaccumulation pathway [32], especially via vegetables and root tubers consumption. This bio-concentration and subsequent bio-magnification may cause serious environmental hazard, because presence and $\mathrm{Mn}$ in excess in water, air and food have been linked with poorer attention span and memory $[33,34]$ and hyperactive behavior in young school-aged children [35]. Elevated Mn levels has also been linked with cognitive dysfunction in 10 years-old children [36].

\section{Level of Mn in the soil}

Table 3: Manganese level (mg/kg) in Soils from Vegetables and Root Tubers from Gbe, Mogho, B-Dere, K-Dere, Kpor and Bodo City, Gokana Local Government Area, Ogoniland, Rivers State, Nigeria compared with permissible limit

\begin{tabular}{|c|c|c|c|c|c|c|}
\hline \multicolumn{7}{|c|}{ Mn } \\
\hline & Gbe & Mogho & B-Dere & K-Dere & Kpor & Bodo City \\
\hline USEPA & 500 & 500 & 500 & 500 & 500 & 500 \\
\hline Pumpkin & $49.8 \pm 1.29$ & $37.1 \pm 0.56$ & $50.7 \pm 0.89$ & $56.6 \pm 1.01$ & $36.5 \pm 1.22$ & $61.9 \pm 1.93$ \\
\hline Bitter leaf & $34.4 \pm 1.01$ & $29.0 \pm 1.14$ & $33.5 \pm 1.46$ & $62.4 \pm 2.14$ & $27.1 \pm 1.18$ & $70.3 \pm 2.23$ \\
\hline Water leaf & $28.4 \pm 2.11$ & $29.4 \pm 0.61$ & $43.4 \pm 2.11$ & $52.2 \pm 0.76$ & $36.5 \pm 0.81$ & $63.8 \pm 1.60$ \\
\hline Scent leaf & $43.1 \pm 1.33$ & $31.8 \pm 0.49$ & $37.4 \pm 1.18$ & $48.9 \pm 1.68$ & $43.1 \pm 0.99$ & $88.4 \pm 1.77$ \\
\hline Yam & $54.9 \pm 2.18$ & $39.9 \pm 1.43$ & $71.4 \pm 2.10$ & $82.8 \pm 1.46$ & $38.4 \pm 1.22$ & $82.6 \pm 2.00$ \\
\hline Cocoyam & $41.8 \pm 1.23$ & $34.1 \pm 0.99$ & $54.3 \pm 1.90$ & $55.6 \pm 1.16$ & $44.8 \pm 0.63$ & $92.3 \pm 1.39$ \\
\hline Water yam & $33.4 \pm 1.84$ & $41.4 \pm 1.33$ & $62.1 \pm 1.23$ & $59.8 \pm 0.83$ & $52.3 \pm 1.36$ & $70.3 \pm 1.40$ \\
\hline Cassava & $61.9 \pm 2.44$ & $54.8 \pm 2.11$ & $46.5 \pm 0.71$ & $43.1 \pm 1.47$ & $41.1 \pm 0.98$ & $59.5 \pm 1.81$ \\
\hline
\end{tabular}

The levels of $\mathrm{Mn}$ in different leafy vegetables and root tubers from the soils and it permissible limit are presented in Table 3. The mean level of Mn (mg/kg) in the soil samples of this Gokana coastal communities' farm land showed an elevated level of Mn. The overall results ranged between $27.1 \pm 1.18-88.4 \pm 1.77 \mathrm{mg} / \mathrm{kg}$ in vegetables associated soils and $33.4 \pm 1.84-92.3 \pm 1.39 \mathrm{mg} / \mathrm{kg}$ in root tubers associated soils. The lowest level $(27.1 \pm 1.18 \mathrm{mg} / \mathrm{kg})$ was observed in the soil of vegetable (bitter leaf) from Kpor, while the highest $(88.4 \pm 1.77 \mathrm{mg} / \mathrm{kg})$ was in soil of vegetable (scent leaf) from Bodo City. Also, the lowest and highest (33.4 \pm 1.84 $92.3 \pm 1.39 \mathrm{mg} / \mathrm{kg}$ ) was observed in water yam and cocoyam from Gbe and Bodo City, respectively. Although the level of Mn in the soil of the study sites is below the permissible limit, there is still significant increase in Mn levels observed in the farmland of Gokana communities. The highest contents of Mn may be as results of extensive discharge of crude oil spill and various agrochemicals such as application of fertilizer contaminated with Mn may acts as source of Mn pollution of water, air, soil and food chain. Therefore, Mn could accumulate in the vegetables and root tubers many times above the permissible limit for human consumption and this lead to adverse health effect such as manganism.

\section{The Bio-concentration Factor (BCF)}

The bio-concentration factor of $\mathrm{Mn}$ from soil to the food crops parts was calculated to evaluate the relative uptake of $\mathrm{Mn}$ by the vegetables and root tubers with respect to soil. Over the years, environmental scientists have used the ratio of metals between soil and plant parts as an important parameter for the assessment of soil contaminated with high level of heavy metals. When the ratio is $>1$, it indicates higher bio-accumulation of metals in plant parts than soil [37]. BCF value of a metals is influenced by many factors such as was influenced by different factors such as soil electrolyte, metal chemistry, electrochemical properties (such as temperature, $\mathrm{pH}$ ) and the type of plant. One of the important pathways for human exposure to metals is via the translocation of metals from soil to food crops.

The BCF of $\mathrm{Mn}$ in the vegetables and root tubers are presented in Table 4. The BCF of the food crops from the six communities' coastal farmlands followed the order: Bodo city $>$ Gbe $>$ Mogho $>$ B-Dere > K-Dere > Kpor. The higher BCF was obtained for cassava from B-Dere, Gbe and Bodo City in an increasing order. In the overall BCF results ranged between 0.06-1.03. There is corresponding increase in the level of $\mathrm{Mn}$ in the food crops and 
it associated soils, which influence the level of BCF greatly, this is in agreement with $[38,39]$. It suggested that elevated level of Mnin these food crops may be very dangerous for human health because of its high mobility and toxicity. It is important to note that long-term exposure to Mn can cause several health problems such as mitochondrial damage and decrease in ATP production which may lead to activation of apoptotic pathways and necrosis [40]. Also has been found to be a developmental neuro-toxicant that is associated with lower intellectual function, impaired motor skills, hyperactivity and reduced olfactory function in children [41,42]. Taken together, Mn can enter into the food chain and cause several adverse human health outcomes.

Table 4: Bio-concentration Factor (BCF)of Manganese from Soil and Vegetables/Root Tubers fromGbe, Mogho, B-Dere, K-Dere, Kpor and Bodo City, Gokana Local Government Area, Ogoniland, Rivers State, Nigeria.

\begin{tabular}{|c|c|c|c|c|c|c|}
\hline & Gbe & Mogho & B-Dere & K-Dere & Kpor & Bodo City \\
\hline Pumpkin & 0.57 & 0.44 & 0.26 & 0.14 & 0.11 & 0.28 \\
\hline Bitter leaf & 0.3 & 0.31 & 0.2 & 0.18 & 0.17 & 0.33 \\
\hline Water leaf & 0.52 & 0.48 & 0.19 & 0.12 & 0.06 & 0.44 \\
\hline Scent leaf & 0.2 & 0.26 & 0.16 & 0.11 & 0.1 & 0.19 \\
\hline Yam & 0.76 & 0.49 & 0.52 & 0.38 & 0.28 & 0.64 \\
\hline Cocoyam & 0.66 & 0.27 & 0.52 & 0.43 & 0.18 & 0.42 \\
\hline Water yam & 0.56 & 0.34 & 0.28 & 0.33 & 0.25 & 0.32 \\
\hline Cassava & 0.91 & 0.39 & 0.89 & 0.83 & 0.47 & 1.03 \\
\hline
\end{tabular}

The overall extent of contamination by $\mathrm{Mn}$ in the study sites was evaluated using BCF, the result is shown in Table 5. It was observed that CF level in Ghe, Mogho and Kpor has very slight contamination level in all the vegetables and root tubers examined except pumpkin, yam and cassava from Gbe, cassava for Mogo and water yam for Kpor that slight contamination were recorded. Slight contamination was also recorded for most of the food samples from other study sites. The ability of metals to bioaccumulate in food crops is a great cause for concern especially in

developing countries like Nigeria were citizens depend more on root tubers (cassava, yam etc.) for food. In fact, cassava is one of the most important food crops in Nigeria. Also, leafy vegetables cultivated in the study communities are highly consumed by the populace. Reports have indicated that vegetables showed preferential transfer for $\mathrm{Mn}, \mathrm{Cd}$ and $\mathrm{Pb}$ in polluted soil [43]. Lacatusu et al. [44] has reported that consumption of toxic metals contaminated vegetables may reduce life expectancy by 9-10 years.

Table 5: Concentration Factor (CF)of Manganese from Soil and Vegetables/Root Tubers fromGbe, Mogho, B-Dere, K-Dere, Kpor and Bodo City, Gokana Local Government Area, Ogoniland, Rivers State, Nigeria

\begin{tabular}{|c|c|c|c|c|c|c|}
\hline & Gbe & Mogho & B-Dere & K-Dere & Kpor & Bodo City \\
\hline Pumpkin & 0.1 & 0.08 & 0.11 & 0.12 & 0.08 & 0.13 \\
\hline Bitter leaf & 0.07 & 0.06 & 0.07 & 0.13 & 0.06 & 0.15 \\
\hline Water leaf & 0.06 & 0.06 & 0.09 & 0.11 & 0.08 & 0.13 \\
\hline Scent leaf & 0.09 & 0.07 & 0.08 & 0.1 & 0.09 & 0.19 \\
\hline Yam & 0.12 & 0.08 & 0.15 & 0.17 & 0.08 & 0.17 \\
\hline Cocoyam & 0.09 & 0.07 & 0.11 & 0.12 & 0.09 & 0.19 \\
\hline Water yam & 0.07 & 0.09 & 0.13 & 0.13 & 0.11 & 0.15 \\
\hline Cassava & 0.13 & 0.11 & 0.1 & 0.1 & 0.09 & 0.13 \\
\hline
\end{tabular}

Because vegetables and root tubers are the most important constituent of human diet in Gokana, River State, human health risks assessment due to daily intake of Mn via consumption of vegetables and root tubers to the study population evaluated. The estimated daily intakes (EDI) of Mn via consumption of vegetables and root tubers are presented in Table 6. The highest maximum EDI was found for Mn in yam and cassava (12.8 and $12.0 \mathrm{mg} / \mathrm{kg} /$ day, respectively) for children and less than one for adults. If individual $(70 \mathrm{mg} / \mathrm{kg})$ consumes approximately 0.220 and $0.345 \mathrm{mg} / \mathrm{kg} /$ day vegetables and 0.361 and $0.586 \mathrm{mg} / \mathrm{kg} /$ day for root tubers [29]. Therefore, taking into consideration that the different expose population may have different vegetables and root tubers consumption rate throughout, it may be plausible to evaluate the average intake of Mn from vegetables and root tubers. The EDI was considerably low for vegetables and root tubers evaluated for adults but alarmingly high for EDI evaluated for Children. 


\section{Current Trends in Biomedical Engineering \& Biosciences}

Table 6: Estimated Daily Intake (EDI) of Manganese in Vegetables and Root Tubers from Gbe, Mogho, B-Dere, K-Dere, Kpor and Bodo City, Gokana Local Government Area, Ogoniland, Rivers State, Nigeria

\begin{tabular}{|c|c|c|c|c|c|c|c|}
\hline \multicolumn{8}{|c|}{ Mn } \\
\hline & Gbe & Mogho & B-Dere & K-Dere & Kpor & Bodo City & \\
\hline \multirow[t]{2}{*}{ Pumpkin } & Adult & 0.14 & 0.08 & 0.07 & 0.04 & 0.02 & 0.09 \\
\hline & Children & 0.39 & 0.23 & 0.18 & 0.11 & 0.06 & 0.24 \\
\hline \multirow[t]{2}{*}{ Bitter leaf } & Adult & 0.05 & 0.04 & 0.03 & 0.06 & 0.02 & 0.11 \\
\hline & Children & 0.14 & 0.13 & 0.09 & 0.16 & 0.06 & 0.31 \\
\hline \multirow[t]{2}{*}{ Water leaf } & Adult & 0.07 & 0.07 & 0.04 & 0.03 & 0.01 & 0.14 \\
\hline & Children & 0.2 & 0.19 & 0.12 & 0.09 & 0.03 & 0.34 \\
\hline \multirow[t]{2}{*}{ Scentleaf } & Adult & 0.04 & 0.04 & 0.03 & 0.03 & 0.02 & 0.08 \\
\hline & Children & 0.12 & 0.11 & 0.08 & 0.08 & 0.06 & 0.22 \\
\hline \multirow[t]{2}{*}{ Yam } & Adult & 0.35 & 0.16 & 0.31 & 0.27 & 0.09 & 0.44 \\
\hline & Children & 9.46 & 4.56 & 8.39 & 7.17 & 2.44 & 12 \\
\hline \multirow[t]{2}{*}{ Cocoyam } & Adult & 0.23 & 0.08 & 0.24 & 0.2 & 0.07 & 0.32 \\
\hline & Children & 6.2 & 2.06 & 6.43 & 5.45 & 1.83 & 8.69 \\
\hline \multirow[t]{2}{*}{ Wateryam } & Adult & 0.16 & 0.12 & 0.14 & 0.17 & 0.11 & 0.19 \\
\hline & Children & 4.23 & 3.14 & 3.91 & 4.48 & 2.96 & 5.16 \\
\hline \multirow[t]{2}{*}{ Cassava } & Adult & 0.47 & 0.18 & 0.35 & 0.3 & 0.16 & 0.51 \\
\hline & Children & 12.8 & 4.86 & 9.37 & 8.05 & 4.37 & 13.9 \\
\hline
\end{tabular}

Target Hazard Quotient (THQ) index was calculated to assess human the health risks associated with the consumption of Mn via dietary intake of vegetables and root tubers as presented in Table 7. The Mean THQ values of Mn in the study sites for each vegetables and root tubers have the following THQ for health risks: Body City (adults :0.57-3.64 and children: 2.21-99.3), Gbe (adults: 0.29-3.36 and children: 0.86-91.4), B-Dere (adults: 0.21-2.50 and children: 0.57-66.9), K-Dere (adults: 0.21-2.14 and children: 0.57-57.5), Mogho (0.29-1.29 and children: 0.7934.7) and Kpor (0.07-0.79 and children: 0.21-31.2). About $55.2 \%$ of THQ calculated were $>1$. This results indicate that Mn was 0-99.3 >1. The daily intake of Mn via the consumption of vegetables and root tubers especially are more likely to pose severe health risks to exposed population [45] in Gokana. The assessment of Mn health risks to Gokana exposed population via local consumption of leafy vegetables and root tubers accounts for $80 \%$ of total leafy vegetables and root tubers consumed in Gokana communities. The risks of $\mathrm{Mn}$ and other toxic metals contamination and their long-term interactions with other contaminants can induce distinct health and ecological risks via addictive, antagonistic and/or synergistic effects [43,46,47]. It is important to note that THQ calculated indicates that children are more susceptible to Mn toxicity than adults.

Table 6: Target Hazard Quotient (THQ) of Manganese in Vegetables and Root Tubers from Gbe, Mogho, B-Dere, K-Dere, Kpor and Bodo City, Gokana Local Government Area, Ogoniland, Rivers State, Nigeria.

\begin{tabular}{|c|c|c|c|c|c|c|c|}
\hline \multicolumn{2}{|c|}{} \\
& Gbe & Mogho & B-Dere & K-Dere & Kpor & Bodo City \\
\hline Pumpkin & Adult & 1 & 0.57 & 0.5 & 0.29 & 0.14 & 0.64 \\
\hline & Children & 2.79 & 1.64 & 1.29 & 0.79 & 0.43 & 1.71 \\
\hline Bitter leaf & Adult & 0.36 & 0.29 & 0.21 & 0.43 & 0.14 & 0.79 \\
\hline & Children & 1 & 0.93 & 0.64 & 1.14 & 0.43 & 2.21 \\
\hline Water leaf & Adult & 0.5 & 0.5 & 0.29 & 0.21 & 0.07 & 1 \\
\hline & Children & 1.43 & 1.36 & 0.86 & 0.64 & 0.21 & 2.43 \\
\hline Scentleaf & Adult & 0.29 & 0.29 & 0.21 & 0.21 & 0.14 & 0.57 \\
\hline & Children & 0.86 & 0.79 & 0.57 & 0.57 & 0.43 & 1.57 \\
\hline Yam & Adult & 2.43 & 1.14 & 2.21 & 1.93 & 0.64 & 3.14 \\
\hline & Children & 67.6 & 32.6 & 59.9 & 52.2 & 17.4 & 85.7 \\
\hline Cocoyam & Adult & 1.64 & 0.57 & 1.71 & 1.43 & 0.5 & 2.29 \\
\hline & Children & 44.3 & 14.7 & 45.9 & 38.9 & 13.1 & 62.1 \\
\hline
\end{tabular}




\section{Current Trends in Biomedical Engineering \& Biosciences}

\begin{tabular}{|c|c|c|c|c|c|c|c|}
\hline Wateryam & Adult & 1.14 & 0.86 & 1 & 0.21 & 0.79 & 1.36 \\
\hline & Children & 30.2 & 22.4 & 27.9 & 32 & 21.1 & 36.9 \\
\hline Cassava & Adult & 3.36 & 1.29 & 2.5 & 2.14 & 0.14 & 3.64 \\
\hline & Children & 91.4 & 34.7 & 66.9 & 57.5 & 31.2 & 99.3 \\
\hline
\end{tabular}

\section{Conclusion}

In this present study, there was significant difference in Mn levels in vegetables and root tubers from Gbe, Mogho, B-Dere, K-Dere, Kpor and Bodo City. Vegetables and root tubers from Bodo City bio-accumulate Mn more than study sites in this present study. From the pollution index and health risk assessment calculated, there was significant uptake of Mn by the studied food crops and great health risk from their consumption. Long-term bioaccumulation of $\mathrm{Mn}$ in and subsequent uptake by food crops may lead to significant public health risks. It is important to note that the human health risks indicated that metals ingestion is the most exposure pathways and in this present study children are more susceptible to Mn toxicity than adults. Its recommended that the populace in Gokana avoid eating food crops from this contaminated communities, especially in Bodo City so as to avoid bio-accumulate Mn which is neurotoxic at high level in the body. Thus regulating bodies like DPR should ensure regular monitoring of Mn and other toxic metals from industrial effluents, heavy trucks, sewage and crude oil spill in foods and soils, which is very essential to prevent their excessive bio-accumulation in the food chain.

\section{References}

1. Liu FZ, Peng SW, Shi RG, Zhang TL, Zhao YJ, et al. (2008) Cadmium accumulation in soil and crops and pollution risks to human health under different land use types. Resour Sci 30(12): 1904-1909.

2. Khan S, Reid BJ, Li G, Zhu YG (2014) Application of biochar to soil reduces cancer risk via rice consumption: a case study in Miaoqian village, Longyan, China. Environ Int 68: 154-161.

3. Chen H, Teng Y, Lu S, Wang Y, Wu J, et al. (2016) Source apportionment and health risk assessment of trace metals in surface soils of Beijing metropolitan, China. Chemosphere 144: 1002-1011.

4. Shaheen N, Irfan NM, Khan IN, Islam S, Islam MS, et al. (2016) Presence of heavy metals in fruits and vegetables: health risk implications in Bangladesh. Chemosphere 152: 431-438.

5. Jarup L (2003) Hazards of heavy metal contamination. Br Med Bull 68: 167-182.

6. Sathawaral NG, Parikh DJ, Agarwal YK (2004) Essential heavymetals in environmental samples from Western India. Bull Environ Contam Toxicol 73(4): 756-761.

7. Singh A, Sharma KR, Agrawal M, Marshall FM (2010) Health risk assessment of heavy metals via dietary intake of foodstuffs from the wastewater irrigated site of a dry tropical area of India. Food Chem Toxicol 48(2): 611-619.

8. Nabulo G, Black CR, Young SD (2011) Trace metal uptake by tropical vegetables grown on soil amended with urban sewage sludge. Environ Poll 159(2): 368-376

9. Arora M, Kiran B, Rani S, Rani A, Kaur B, et al. (2008) Heavy metal accumulation in vegetables irrigated with water from different sources. Food Chem 111(4): 811-815.
10. Eliku T, Leta S (2017) Heavy metals bioconcentration from soil to vegetables and appraisal of health risk in Koka and Wonji farms, Ethiopia. Environ Sci Pollut Res Int 24(12): 11807-11815.

11. Aschner M, Aschner JL (1991) Manganese neurotoxicity: cellular effects and blood-brain barrier transport. Neurosci Biobehav Rev 15(3): 333-340.

12. Erikson KM, Syversen T, Steinnes E, Aschner M (2004) Globus pallidus: a target brain region for divalent metal accumulation associated with dietary iron deficiency. J Nutr Biochem 15(6): 335341.

13. Cersosimo MG, Koller WC (2006) The diagnosis of manganeseinduced parkinsonism. Neurotoxicology 27(3): 340-346.

14. Bowler RM, Gysens S, Diamond E, Nakagawa S, Drezgic M, et al (2006) Manganese exposure: neuropsychological and neurological symptoms and effects in welders. Neurotoxicology 27(3): 315-326.

15. Bouchard M, Mergler D, Baldwin M, Panisset M, Roels HA (2007) Neuropsychiatric symptoms and past manganese exposure in a ferro-alloy plant. Neurotoxicology 28(2): 290-297.

16. Guilarte TR, Burton NC, McGlothan JL, Verina T, Zhou Y, et al. (2008) Impairment of nigrostriatal dopamine neurotransmission by manganese is mediated by pre-synaptic mechanism(s): implications to manganese-induced parkinsonism. J Neurochem 107(5): 12361247.

17. Guilarte TR (2010) Manganese and Parkinson's disease: a critical review and new findings. Environ Health Perspect 118(8): 10711080.

18. Voutsa D, Grimanis A, Samara C (1996) Trace elements in vegetables grown in industrial areas in relation to soil and air particulate matter Environ Poll 94(3): 325-335.

19. Garg VK, Yadav P, Mor S, Singh B, Pulhani V (2014) Heavy metals bioconcentration from soil to vegetables and assessment of health risk caused by their ingestion. Biol Trace Element Res 157(3): 256-265.

20. Shah MT, Shaheen B, Khan S (2010) Pedo and biogeochemical studies of mafic and ultramafic rocks in the Mingora and Kabal areas, Swat, Pakistan. Environ Earth Sci 60(5): 1091-1102.

21. Nkpaa KW, Onyeso GI, Achugasim 0 (2017) Heavy metals levels in shellfish from Bodo City and B-Dere, Ogoniland, Rivers State, Nigeria, and evaluation of possible health risks to consumers. Sustain. Water Resour Manag 3(1): 83-91.

22. Nkpaa KW, Patrick-Iwuanyanwu KC, Wegwu MO, Essien EB (2016) Health risk assessment of hazardous metals for population via consumption of seafood from Ogoniland, Rivers State, Nigeria; a case study of Kaa, B-Dere, and Bodo City. Environ Monit Assess 188(1): 9.

23. Itanna F (2002) Metals in leafy vegetables grown in Addis Ababa and toxicological implications. Ethiop J Health Dev 16(3): 295-302.

24. Wang Q, Dong Y, Cui Y, Liu X (2001) Instances of soil and crop heavy metal contamination in china. Soil Sed Cont 10(5): 497-510.

25. Sobukola OP, Adeniran OM, Odedairo AA, Kajihausa OE (2010) Heavy metal levels of some fruits and leafy vegetables from selected markets in Lagos, Nigeria. African J Food Sci 4(2): 389-393.

26. Lacatusu R (2000) Appraising levels of soil contamination and pollution with heavy metals. In: Heinike HJ, Eckselman W, Thomasson AJ, Jones RJA, Montanarella L, et al. (Eds.), Land information systems 
for planning the sustainable use of land resources. European Soil Bureau Research Report, Office of Official Publication of the European Communities, Luxembourg, vol 200, pp. 393-402.

27. Ihedioha JN, Ukoha PO, Ekere NR (2017) Ecological and human health risk assessment of heavy metal contamination in soil of a municipal solid waste dump in Uyo, Nigeria. Environ Geochem Health 39(3): 497-515.

28. DPR (Department of petroleum resources) (2002) Environmental guidelines and standards for the petroleum industry in Nigeria (revised edn), Nigeria: Ministry of Petroleum and Natural Resources, Department of Petroleum Resources.

29. Orisakwe OE, Nduka JK, Amadi CN, Dike DO, Bede O (2012) Heavy metals health risk assessment for population via consumption of food crops and fruits in Owerri, South Eastern, Nigeria. Chem Cent J 6(1): 77.

30. Inter-réseaux (2010) Staple Crop Production and Consumption: Nigeria on the Way to Food Self-Sufficiency. Grain de sel 51: 10-12.

31. USEPA (2005) Region 6, Human Health Risk Assessment Protocol Chapter 7: Characterizing Risk and Hazard, Multimedia Planning and Permitting Division. Office of Solid Waste, Center for Combustion Science and Engineering.

32. Kashif SR, Akram M, Yaseen M, Ali S (2009) Studies on heavy metals status and their uptake by vegetables in adjoining areas of Hudiara drain in Lahore. Soil Environ 28(1): 7-12.

33. Oulhote Y, Mergler D, Barbeau B, Bellinger DC, Bouffard T, et al (2014) Neurobehavioral function in school-age children exposed to manganese in drinking water. Environ Health Perspect 122(12): $1343-1350$

34. Carvalho CF, Menezes-Filho JA, Matos VP, Bessa JR, Coelho-Santos J, et al. (2014) Elevated airborne manganese and low executive function in school-aged children in Brazil. Neurotoxicology 45: 301-308.

35. Bouchard M, Laforest F, Vandelac L, Bellinger D, Mergler D (2007) Hair manganese and hyperactive behaviors: pilot study of schoolage children exposed through tap water. Environ Health Perspect 115(1):122-127.

36. Wasserman GA, Liu X, Parvez F, Ahsan H, Levy D, et al. (2006) Water manganese exposure and children's intellectual function in Araihazar Bangladesh. Environ Health Perspect 114(1): 124-129.
37. Barman SC, Sahu RK, Bhargava SK, Chatterjee C (2000) Distribution of heavy metals in wheat, mustard and weed grown in fields irrigated with industrial effluents. Bull Environ Contam Toxicol 64(4): 489496.

38. Khan K, Lu Y, Khan H, Ishtiaq M, Khan S, et al. (2013) Heavy metals in agricultural soils and crops and their health risks in Swat District, northern Pakistan. Food Chem Toxicol 58: 449-458.

39. Abbasi AM, Iqbal J, Khan MA, Shah MH (2013) Health risk assessment and multivariate apportionment of trace metals in wild leafy vegetables from lesser Himalayas, Pakistan. Ecotoxicol Environ Saf 92: $237-244$.

40. Roth JA, Horbinski C, Higgins D, Lein P, Garrick MD (2002) Mechanisms of manganese-induced rat pheochromocytoma (PC12) cell death and cell differentiation. Neurotoxicology 23(2): 147-157.

41. Zoni S, Lucchini RG (2013) Manganese exposure: cognitive, motor and behavioral effects on children: a review of recent findings. Curr Opin Pediatr 25(2): 255-260.

42. Grandjean P, Landrigan PJ (2014) Neurobehavioural effects of developmental toxicity. Lancet Neurol 13(3): 330-338.

43. Chang CY, Yu HY, Chen JJ, Li FB, Zhang HH, et al. (2014) Accumulation of heavy metals in leaf vegetables from agricultural soils and associated potential health risks in the Pearl River Delta, South China. Environ Monit Assess 186(3): 1547-1560.

44. La`čtuşu R, Răuță C, Cârstea S, Ghelase I (1996) Soilplant- man relationships in heavy metal polluted areas in Romania. Applied Geochemistry 11(1-2): 105-107.

45. Huang ML, Zhou SL, Sun B, Zhao QG (2008) Heavy metals in wheat grains: assessment of potential health risk for inhabitants in Khunshan, China. Sci Tota Env 405(1-3): 54-61.

46. Menzie CA, Ziccardi LM, Lowney YW, Fairbrother A, Shock SS, et al. (2009) Importance of considering the framework principles in risk assessment for metals. Environ Sci Technol 43(22): 8478-8482.

47. Nordberg GF, Jin T, Hong F, Zhang A, Buchet JP, et al. (2005) Biomarkers of cadmium and arsenic interactions. Toxicol Appl Pharmacol 206(2): 191-197. 